\title{
Anti-Diabetic Effects of Leaves of Trigonella foenum- graecum L. (Fenugreek): Leads from Preclinical Studies
}

Manjeshwar Shrinath Baliga ${ }^{*}$, Princy Louis Palatty ${ }^{2}$, Mohammed Adnan ${ }^{2}$, Taresh Shekar Naik², Pratibha Sanjay Kamble ${ }^{2}$, Thomas George ${ }^{2}$ and Jason Jerome D'souza ${ }^{2}$

${ }^{1}$ Mangalore Institute of Oncology, Pumpwell, Mangalore, Karnataka, 575002, India

${ }^{2}$ Father Muller Medical College, Mangalore, Karnataka, 575002, India

Correspondence to:

Manjeshwar Shrinath Baliga

Mangalore Institute of Oncology, Pumpwell

Mangalore, Karnataka, 575002, India

Tel: +919945422961

E-mail: msbaliga@gmail.com

Received: February 20, 2017

Accepted: May 26, 2017

Published: May 29, 2017

Citation: Baliga MS, Palatty PL, Adnan M, Naik TS, Kamble PS, et al. 2017. Anti-Diabetic Effects of Leaves of Trigonella foenum-graecum L. (Fenugreek): Leads from Preclinical Studies. $J$ Food Chem Nanotechnol 3(2): 67-71.

Copyright: (C) 2017 Baliga et al. This is an Open Access article distributed under the terms of the Creative Commons Attribution 4.0 International License (CC-BY) (http://creativecommons. org/licenses/by/4.0/) which permits commercial use, including reproduction, adaptation, and distribution of the article provided the original author and source are credited.

Published by United Scientific Group

\begin{abstract}
Diabetes mellitus, a metabolic disorder of the endocrine system is one of the World's oldest diseases known to man. Since time immemorial plants have been used as anti-diabetic agents in the various traditional systems of medicine. Trigonella foenum-graecum commonly known as fenugreek in English and methi in various Indian languages is one such plant and has been an integral part in the treatment of diabetes in the Indian traditional system of medicine the Ayurveda. The seeds and leaves have been documented to be useful in reducing hyperglycemia and its complications. This review collates the traditional uses and validated anti-diabetic effects of the fenugreek leaves and on the mechanisms contributing to the therapeutic effects.
\end{abstract}

\section{Keywords}

Trigonella foenum-graecum, Fenugreek, Methi leaves, Diabetes

\section{Introduction}

Recent information from around the world has affirmatively confirmed that type II diabetes mellitus (DM), a metabolic disorder of the endocrine system is a major malady and that it is major health issue in India and China [1, 2]. From a medical perspective, the hyperglycemia resulting from the inadequate response of target cells to insulin causes glucotoxicity and consequentially causes long term side vascular and non-vascular complications [2,3]. The most important vascular complications include retinopathy, nephropathy, neuropathy, coronary and peripheral artery and cerebrovascular ailments, while the most important non vascular complications includes gastroparesis, infections and skin changes $[2,3]$. These secondary ailments merit regular and judicious medical attention inevitably affecting the individuals and their families at large [1]. From a mechanistic perspective, how hyperglycemia causes dysfunction of multiple organs is unknown. However, comparative molecular and biochemical studies are indicating the facts that activation of protein kinase $\mathrm{C}$, formation of advanced glycosylation end products, increased sorbitol production, activation of hexosamine pathway and production of free radicals [reactive oxygen species (ROS) and reactive nitrogen species (RNS) cumulatively contribute towards the observed endothelial dysfunction and cellular damage $[2,3]$.

From a treatment perspective diabetes is usually treated with subcutaneous injections of insulin, oral hypoglycemic drugs like the insulinsensitizers (biguanides, thiazolidinediones), insulin secretagogues (sulfonylureas, meglitinides), $\alpha$-glucosidase inhibitors, incretin agonists and dipeptidyl peptidase- 4 inhibitors [4]. However, the use of these drugs is associated with untoward side effects 
like hypoglycemia and localized lipoatrophy at the site of injection with insulin injection; acidosis and renal failure with metformin; fluid retention, weight gain and increased the risk of fracture with thiazolidinediones; abdominal discomfort, flatus, diarrhea, jaundice and cholestasis with alpha glucosidase inhibitors; nausea, pancreatitis and severe allergic reactions with glucagon like peptide (GLP 1) analogues; and nausea with amylin agonists $[2,4]$. Despite being effective in reducing hyperglycemia, the presently available drugs are incapable of halting the progression of the disease and prevent complications. In lieu of these observations, discovering newer anti-diabetic agents especially from dietary sources and with medicinal properties is beneficial for these agents would be cheaper, orally administrable, possess fewer side effects and have easy acceptability $[5,6]$.

\section{Trigonella foenum-graecum the all season plant}

Among the various medicinal plants documented to be of use as a hypoglycemic agent, Trigonella foenum-graecum commonly known as fenugreek in English and methi in various Indian languages is important dietary and medicinal plants $[7,8]$. The other names are enlisted in Table 1 . The plant is annual and grows to an average height of two feet. Documents indicate that it is one of the oldest medicinal agents to be used in the treatment of diabetes in the various traditional and folk systems of medicine [8]. The plants were originally native to India and Northern Africa, but are today found growing in other parts of the world. The seeds, maturing in long pods and tender leaves are the plant parts used in various medicinal preparations as well as a spice in Indian curries [8]. The taxonomic classification of Trigonella foenumgraecum is as follows:

\section{Kingdom: Plantae}

Super division: Angiosperms

Division: Eudicots

Class: Rosids

Order: Fabales

Family: Fabaceae

Subfamily: Faboideae

Tribe: Trifolieae

Genus: Trigonella

Species: Foenum

\section{Dietary and culinary use of fenugreek}

Fenugreek and seeds have been an integral component of Indian, Pakistani, Bangladeshi and Sri Lankan cuisine and has wide use in variety of dishes like pickles and curry [7, 9]. The seeds are used as flavoring agent for various dishes and is also used a seasoning agents. The sprouted seeds are used as salads while the fresh stems and leaves are used to make pakodas, and curry with lentils [7, 9]. In Egypt and Ethiopia, fenugreek seeds are used in baking bread, while in Switzerland they are used as a flavoring agent in making of cheese $[7,9$, 10]. Fenugreek has been used for centuries in European countries as a spice $[7,9]$. However, its use in USA has been very recently and is principally used as a spice for soups and stews $[7,9]$. The young plants and the leaves (Figure 1) are a very important source of vegetable and have been used in various cuisines $[7,9]$.

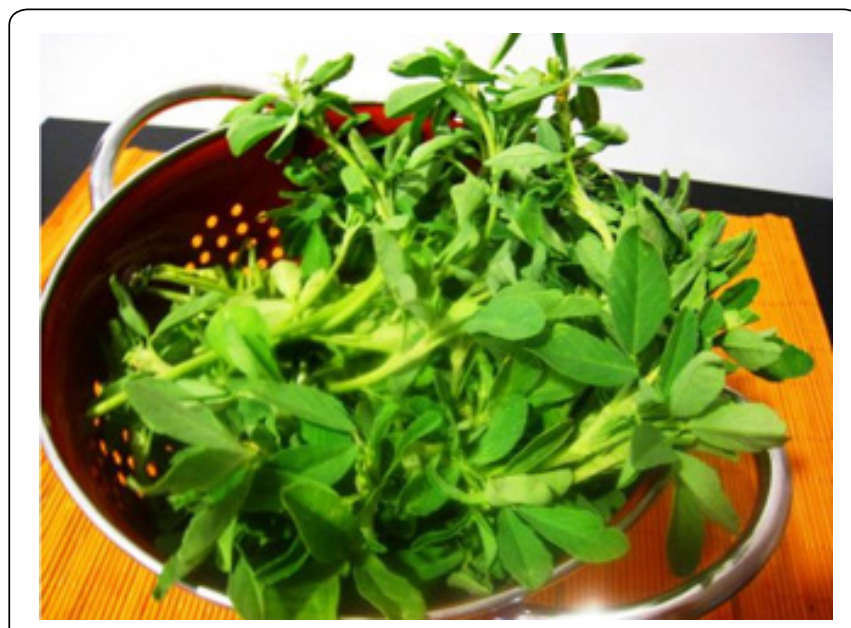

Figure 1: Fenugreek leaves.

\section{Phytochemistry of fenugreek}

Fenugreek is one of the most well investigated plants and studies have it to possess alkaloids like trimethylamine, neurin, trigonelline, choline, gentianine, carpaine and betaine; the amino acids isoleucine, 4-hydroxyisoleucine, histidine, leucine, lysine, 1-tryptophan, arginine; saponins like graecunins, fenugrin $b$, fenugreekine, trigofoenosides $a-g$; the steroidal sapinogens yamogenin, diosgenin, smilagenin, sarsasapogenin, tigogenin, neotigogenin, gitogenin, neogitogenin, yuccagenin, saponaretin; flavonoids like quercetin, rutin, vitexin, isovitexin; the lipids triacylglycerols, diacylglycerols, monoacylglycerols, phosphatidylcholinephosphatidyl ethanolamine, phosphatidylinositol, free fatty acids and lipids, vitamins, minerals. $28 \%$ mucilage; $22 \%$ proteins; $5 \%$ of strong smelling, bitter fixed oil $[7,9,11-13]$. Reports also suggest that fresh fenugreek leaves contain ascorbic acid $(220.97 \mathrm{mg} / 100 \mathrm{~g})$ and $\beta$-carotene (19 $\mathrm{mg} / 100 \mathrm{~g}$ ) [14] and are a rich source of calcium, iron and zinc content [8].

\section{Traditional and validated medicinal uses}

Fenugreek has been an important medicinal agent in the Indian, Chinese, Arabic, Greek and Latin pharmacopoeia [9]. Historical reports indicate that fenugreek was used in ancient Egypt to incense and to embalm mummies [8]. They were also used to relieve menstrual cramps, reduce abdominal pain, ease childbirth and as a lactagogue to increase milk flow in the mother [9]. The ancient Romans fenugreek seeds to facilitate labor and delivery; while in the traditional Chinese medicine it has been used as a tonic and to mitigate weakness and edema of the legs [8].

Fenugreek finds wide use in the Indian traditional systems of medicine the Ayurveda, Siddha and Unani and also in various folk medicines as an aphrodisiac agent, to mitigate digestive and respiratory problems [8, 15]. Fenugreek has been used in the folk medicines for treating cellulitis, boils, 
Table 1: Colloquial name of Fenugreek in various languages.

\begin{tabular}{|c|c|}
\hline Language & Fenugreek \\
\hline Albanian & Kopër Greqie, Trëndetina yzerlike, \\
\hline Amharic & Bish \\
\hline Arabic & Hulba, Hilbeh \\
\hline Aramaic & Pila, Qart, Shebbelila \\
\hline Armenian & Chaiman \\
\hline Assamese & Methi, Mithi, Mithi guti \\
\hline Basque & Allibre, Allorbe \\
\hline Bengali & Methi \\
\hline Bodo & Mithi \\
\hline Bulgarian & Sminduh, Sminduh grutski, Tilchets, Chimen \\
\hline Burmese & Penantazi \\
\hline Catalan & Fenigrec \\
\hline Chinese (Cantonese) & Wuhlouhba \\
\hline Chinese (Mandarin) & Hu luba \\
\hline Coptic & Ali, Jofi, Tili \\
\hline Croatian & Grčka djetlina, Grčko sijeno, Piskavica \\
\hline Czech & Pískavice řecké seno, Senenka \\
\hline Danish & Bukkehornskløver, Bukkehorns-frø \\
\hline Dhivehi & Oabaiy, Oabath \\
\hline Dogri & Methi \\
\hline Dutch & Fenegriek \\
\hline Esperanto & Fenugreko \\
\hline Estonian & Kreeka lambalääts, Põld-lambalääts \\
\hline Farsi & Shanbalile \\
\hline Finnish & Sarviapila \\
\hline French & Fenugrec, Sénegré, Trigonelle \\
\hline Galician & Fenogreco, Alforfa \\
\hline German & Bockshornklee, Griechisch Heu \\
\hline Georgian & olinji, Chaman \\
\hline Greek & Trigonella, Moschositaro \\
\hline Greek (Old) & Telis, Boukeros \\
\hline Gujarati & Methi \\
\hline Hebrew & Hilbeh \\
\hline Hindi & Methi \\
\hline Hungarian & Görögszéna \\
\hline Indonesian & Kelabet, Klabat, Kelabat \\
\hline Italian & Fieno greco \\
\hline Japanese & Koruha, Fenu-guriku \\
\hline Kannada & Mente, Mentya \\
\hline Kashmiri & Meth \\
\hline Korean & Horopa, Penigurik \\
\hline Latin & Fænum Græcum \\
\hline Latvian & Sierāboliņš \\
\hline Lithuanian & Vaistinė ožragė \\
\hline Macedonian & Grčko seme \\
\hline Maithili & Methi \\
\hline Malay & Halba, Kelabet \\
\hline
\end{tabular}

\begin{tabular}{|c|c|}
\hline Malayalam & Uluva, Venthayam \\
\hline Manipuri & Methi \\
\hline Marathi & Methi \\
\hline Mongolian & Grek Chireg \\
\hline Nepali & Methi \\
\hline Newari & $\mathrm{Mi}$ \\
\hline Norwegian & Bukkehornkløver \\
\hline Oriya & Methi \\
\hline Pahlavi & Shabaliidag \\
\hline Polish & Kozieradka pospolita; Nasiona kozieradki \\
\hline Portuguese & Feno-grego, Alfarva, Alforba, Fenacho \\
\hline Provençal & Senigré \\
\hline Punjabi & Methi \\
\hline Romanian & Molotru, Molotru comun, Schinduf \\
\hline Russian & $\begin{array}{l}\text { Pazhitnik grecheski, Shambala, Pazhitnik } \\
\text { cennoj }\end{array}$ \\
\hline Sanskrit & Methika \\
\hline Serbian & Piskavica, Grčko seme \\
\hline Sinhala & Uluhal \\
\hline Slovak & Pískavica, Senovka grécka \\
\hline Slovenian & Grško seno, Sabljasti triplat \\
\hline Spanish & Alholva, Fenogreco \\
\hline Swahili & Uwatu \\
\hline Swedish & Bockhornsklöver \\
\hline Tamil & Meti, Vendayam, Vetani \\
\hline Telugu & Mentikura, Mentulu \\
\hline Thai & Luk sat \\
\hline Tibetan & Mi ti \\
\hline Tigrinya & Abaka \\
\hline Tulu & Mente, Mette \\
\hline Turkish & $\begin{array}{l}\text { Çemen, Poy baharatı, Çimen, Boy tohumu, } \\
\text { Hulbe, Kokulu yonca }\end{array}$ \\
\hline Ukrainian & Hunba sinna \\
\hline Urdu & Methi, Shanbalid \\
\hline Yiddish & Khilbe, Fenigrekum \\
\hline
\end{tabular}

tuberculosis, dysmenorrhea, postmenopausal symptoms, as lactagogue, to relieve colds, bronchial complaints, influenza, asthma, catarrh, constipation, sinusitis, pleurisy, pneumonia, sore throat, laryngitis, hay fever tuberculosis and emphysema [9]. A cross-sectional survey conducted in Sri Lanka has also shown that patients with diabetes use fenugreek indicating that their use is prevalent [8].

Scientific studies carried out in accordance to the tenets of modern medicine have shown fenugreek to possess antidiabetic, antifertility, anticancer, antimicrobial, antiparasitic, lactation stimulant, galactagogue, hypocholesterolemic, immunomodulatory, anti-carcinogenic, anthelmintic, antinociceptive, antioxidant, anti-microbial, anti-ulcer, gastro- 
and hepatoprotective, anti-obesity, anti-hyperglycemic, antidiabetic and hypocholesterolemic effects $[9,16]$. Of these the anti-diabetic properties of the seeds have been investigated the most and reports are suggestive to the fact that the protective effects are seen in both laboratory animal and humans [3, 15]. From a phytochemical perspective the anti-diabetic effects are attributed to the presence of galactomannan, 4-hydroxyisoleucin (4-OH-Ile), diosgenin and trigonelline and detailed mechanistic studies have also shown that 4-hydroxyisoleucin increases insulin secretion, galactomannan to decrease insulin resistance and glucose resorption from the GIT and trigonelline to improve $\beta$-cells regeneration [15].

\section{Methi leaves possess anti-diabetic effects}

Inducing hyperglycemia and evaluating the hypoglycemic effects in laboratory animals has been one of the principal endpoints in ascertain a medicinal agent's effectiveness. With respect to methi leaves, seminal studies by Abdel-Barry and co-workers (1997) [17] showed that the aqueous and alcoholic extracts of the leaf were effective in inducing hypoglycemic activity in both the non-diabetic (normal) and diabetic (alloxan-induced) rats [17]. The investigators tested graded doses of aqueous extract of the leaf by both i.p. (0.06, 0.2, 0.5 , $1 \mathrm{~g} / \mathrm{kg})$ and P.O $(1,2,8 \mathrm{~g} / \mathrm{kg})$ in both normal and alloxandiabetic rats [17]. A significant reduction of blood glucose concentration was noticed also in subsequent studies with the aqueous extracts indicating its usefulness [18].

On a comparative note, the ethanolic extract was observed to be effective only through the i.p. route indicating that the hypoglycemic compound/s were present in the aqueous fraction. The LD50 for i.p. and oral administration were 1.9 and $10 \mathrm{~g} / \mathrm{kg}$ respectively and the liver was the affected part after i.p. administration [17]. Together these data clearly suggest that the aqueous extract of leaves when given both orally and intraperitoneally possesses a hypoglycemic effect in normoglycaemic and alloxan induced hyperglycemic rats and also that the oral route was safe and devoid of any systemic toxic effects [17].

Studies with streptozotocin-induced diabetic rats have also shown that feeding methi leaves improved the body weight, reduced hyperglycemia and the levels of glycosylated hemoglobin [19]. Feeding methi leaves increased the levels of insulin and liver glycogen contents [19]. The anti-diabetic effects of the leaves were similar to that of glibenclamide and that the insulin levels were restored to near normal levels [19]. Feeding methi leaves corrected the diabetes-induced altered levels of the key carbohydrate metabolic enzymes [19] and lipids in serum, liver, heart, and kidney [20].

In addition to the metabolic effects diabetes-induced oxidative stress is a major health issue and fastens the glycotoxic effects on the vital organs. Studies with streptozotocininduced diabetes rats have shown that feeding methi leaves caused a marked reduction in the levels of oxidative stress as affirmed by a decrease in the levels of thiobarbituric acidreactive substances and concomitant increase in levels of reduced glutathione and in activities of catalase and superoxide dismutase in liver, heart, and kidney [21]. Subsequent studies have also confirmed that the aqueous extract of the leaf also caused a concentration dependent decrease in MDA and increase in the levels of GPx and SOD in liver, and WBC [18].

\section{Conclusion}

Scientific studies carried out in the past two decades have shown that methi leaves possess anti-diabetic effects in alloxan and streptozotocin induced diabetic rats. These reports validate believes and use of methi leaves as anti-diabetic agents in various traditional and folk systems of medicine. However clinical data are lacking and is the need of the time. Scientifically designed clinical trial with sufficient sample size and statistical power are required to validate the acclaimed benefits of methi as a natural nutritional treatment for diabetes mellitus. The outcomes of such studies may be useful for the clinical applications of methi in humans and may open up a new therapeutic avenue.

\section{References}

1. Krug EG. 2016. Trends in diabetes: sounding the alarm. Lancet 387(10027): 1485-1486. https://doi.org/10.1016/S0140-6736(16)301 63-5

2. Gwatidzo SD, Williams SJ. 2017. Diabetes mellitus medication use and catastrophic healthcare expenditure among adults aged $50+$ years in China and India: results from the WHO study on global AGEing and adult health (SAGE). BMC Geriatr 17(1): 14. https://doi.org/10.1186/ s12877-016-0408-x

3. Ghorbani A. 2013. Best herbs for managing diabetes: a review of clinical studies. Braz J Pharma Sci 49(3): 413-422. https://doi.org/10.1590/ S1984-82502013000300003

4. Lorenzati B, Zucco C, Miglietta S, Lamberti F, Bruno G. 2010. Oral hypoglycemic drugs: pathophysiological basis of their mechanism of action. Pharmaceuticals (Basel) 3(9): 3005-3020. https://doi. org/10.3390/ph3093005

5. Pfeiffer AF, Klein HH. 2014. The treatment of type 2 diabetes. Dtsch Arztebl Int 111(5): 69-81. https://doi.org/10.3238/arztebl.2014.0069

6. Srinivasan K. 2006. Fenugreek (Trigonella foenum-graecum): a review of health beneficial physiological effects. Food Rev Int 22(2): 203-224. https://doi.org/10.1080/87559120600586315

7. Nathiya S, Durga M, Devasena T. 2014. Therapeutic role of Trigonella foenum-graecum [Fenugreek] - a review. Int J Pharm Sci Rev Res 27(2): $74-80$.

8. Medagama AB, Senadhira D. 2015. Use of household ingredients as complementary medicines for perceived hypoglycemic benefit among Sri Lankan diabetic patients; a cross-sectional survey. $J$ Intercult Ethnopharmacol 4(2): 138-142. https://doi.org/10.5455/ jice. 20150202035223

9. Wani SA, Kumar P. 2017. Fenugreek: a review on its nutraceutical properties and utilization in various food products. J Saudi Society Agri Sci (in press).

10. Thomas JE, Bandara M, Lee EL, Driedger D, Acharya S. 2011. Biochemical monitoring in fenugreek to develop functional food and medicinal plant variants. $N$ Biotechnol 28(2): 110-117. https://doi. org/10.1016/j.nbt.2010.09.001

11. Chatterjee S, Variyar SP, Sharma A. 2010. Bioactive lipid constituents of fenugreek. Food Chem 119(1): 349-353. https://doi.org/10.1016/j. foodchem.2009.05.076

12. Yadav R, Kaushik R, Gupta D. 2011. The health benefits of Trigonellafoenum-graecum: a review. Int J Eng Res Appl 1(1): 32-35.

13. Jain SC, Agrawal M, Sharma RA. 1996. The genus trigonella phytochemistry and biology. Anc Sci Life 16(2): 108-117.

14. Yadav S, Sehgal S. 1997. Effect of home processing and storage on 
ascorbic acid and, ß-carotene content of bathua (Chenopodium album) and fenugreek (Trigonella foenum graecum) leaves. Plant Foods Hum Nutr 50(3): 239-247. https://doi.org/10.1007/BF02436060

15. Koupý D, Kotolová H, RudáKučerová J. 2015. Effectiveness of phytotherapy in supportive treatment of type 2 diabetes mellitus II. Fenugreek (Trigonella foenum-graecum). Ceska Slov Farm 64(3): 67-71.

16. Laila O, Murtaza I. 2015. Fenugreek: a treasure of bioactive compounds with promising antidiabetic potential. International Journal of Food and Nutritional Sciences 4(1): 149-157.

17. Abdel-Barry JA, Abdel-Hassan IA, Al-Hakiem MH. 1997 Hypoglycaemic and antihyperglycaemic effects of Trigonella foenum-graecum leaf in normal and alloxan induced diabetic rats. $J$ Ethnopharmacol 58(3): 149-155. https://doi.org/10.1016/S03788741(97)00101-3
18. Middha SK, Bhattacharjee B, Saini D, Baliga MS, Nagaveni MB, et al. 2011. Protective role of Trigonella foenumgraceum extract against oxidative stress in hyperglycemic rats. Eur Rev Med Pharmacol Sci 15(4): 427-435.

19. Devi BA, Kamalakkannan N, Prince PS. 2003. Supplementation of fenugreek leaves to diabetic rats. Effect on carbohydrate metabolic enzymes in diabetic liver and kidney. Phytother Res 17(10): 1231-1233. https://doi.org/10.1002/ptr.1357

20. Annida B,StanelyMainzen PrinceP.2004.Supplementation of fenugreek leaves lower lipid profile in streptozotocin-induced diabetic rats. J Med Food 7(2): 153-156. https://doi.org/10.1089/1096620041224201

21. Annida B, Stanely Mainzen Prince P. 2005. Supplementation of fenugreek leaves reduces oxidative stress in streptozotocin-induced diabetic rats. J Med Food 8(3): 382-385. https://doi.org/10.1089/ jmf.2005.8.382 